\title{
On some issues of cross-border class actions
}

\author{
Svetlana Grubtsova* \\ Ural State Law University, Civil Procedure Department, Yekaterinburg, Russia
}

\begin{abstract}
At present, globalization imposes the conditions under which legal conflicts are no longer confined to the territory of one state and involve hundreds and thousands of people, both in Russia and abroad. Class actions are becoming global procedural means for collective protection of rights and interests, while the effectiveness of national models of class actions and their adaptation to cross-border conditions are questioned. According to the author, the greatest difficulties in cross-border class actions may arise in determination of amenability and jurisdiction, proper notification of foreign group members and joining the submitted claim, validity of court decisions in the cross-border class action and its recognition and execution, and the exclusion of adjudication of individual accusations in a foreign country after the court decision rendered in the cross-border class action. Based on the analysis of certain aspects, the author suggests that the resolution of issues of recognition and enforcement of court decisions in cross-border class actions can be affected by the models of class actions according to the rules for involving group members in group proceedings (opt-in and opt-out models). The paper provides recommendations for improving the current Russian procedural legislation in the context of development of the institution of class actions in the cross-border aspect, which concern the detailing of the legal regulation of the procedure for notification of foreign group members about the possibility of joining the class action.
\end{abstract}

\section{Introduction}

At the present stage of development of economic relations and civil transactions, increasing globalization expands the range of cross-border legal relations. The entry of Russian companies and citizens of the Russian Federation into private law relations with foreigners leads, in turn, to an increase in the number of crossborder disputes.

The dispute resolution process is less limited to disputed parties from one country and departs from the 'plaintiff-defendant' model in a particular case [1]. Thus, we deal with a situation when not dozens but hundreds and thousands of persons, both in Russia and abroad, are involved in legal conflicts, and the rights and interests of both an indefinite circle of persons and a large personalized group [2].

Modern jurisdictions develop procedural means for collective protection of rights and interests, including a class action as the key one. Despite the legal imperfections of the class action institution [3], its positive legal effect on the protection of large groups of persons cannot be neglected. It is the procedural mechanism of group proceedings that allows plaintiffs to institute legal proceedings not only on their own behalf, but also on behalf of other persons with similar interests. A number of researchers state that in the concept of a class action, a plaintiff, representative of the group, acts as a 'means of achieving' the court decision both in his own substantive action and on the legal actions of other class plaintiffs that are absent [4].
Class actions are beginning to acquire a global perspective and raise some issues about the effectiveness of national models of protecting collective rights and interests through class action and adaptation to these conditions. The issues include the correct determination of the competent court and the mechanisms of notification and joining of foreign members of the group to the claim presented to the court.

\section{Results}

The institute of class action in Russia has gone through certain stages of its normative, legal-practical and doctrinal development. It is obvious that the awareness of the advantages of this method of legal protection, including economic feasibility, procedural economy and social effect, contributed to the development of legislation to empower interested parties to use a class action [5].

As a brief historical insight to understand the subject of research, it should be noted that the Russian class action began and continues its own path, in comparison with foreign jurisdictions. The Russian legislative provisions that took into account the need to protect the rights and interests of large groups of people appeared in the norms of substantive law consolidated in the Law of the Russian Federation On Protection of Consumer Rights (1992), and in the Law of the RSFSR On Environmental Protection (1991). The provisions of these regulatory legal acts have become a basis for the

*Corresponding author: grubtsovas@gmail.com 
development and improvement of procedural means of protecting collective rights and interests. A number of provisions on the protection of an indefinite circle of persons appeared in 2000 in Art. 42 of the former Code of Civil Procedure of the RSFSR.

In the form most consistent with foreign understanding, the concept of a class action in Russia was implemented only in 2009 in the norms of the modern Arbitration Procedure Code of the Russian Federation, when the legislator consolidated Ch. 28.2 Consideration of cases on protection of rights and legitimate interests of a group of persons. However, despite the innovations, domestic science and legal practice criticize this legal regulation, since it did not allow the class action to become the means for protecting the rights and interests of interested parties [6].

The last major changes in the institution of class action in the Russian procedural law took place in 2019 due to the adoption of Federal Law No. 191-FZ of July 18, 2019 On Amendments to Certain Legislative Acts of the Russian Federation. The provisions on the filing of class actions in courts of general jurisdiction in civil proceedings were introduced, and the approaches to the regulation of group proceedings in arbitration proceedings were improved.

Thus, independent, although not unified, procedural regulations for protection of rights and interests through a class action are provided in the Code of Civil Procedure of the Russian Federation (Ch. 22.3), the Code of Arbitration Procedure of the Russian Federation (Ch. 28.2) and the Code of Administrative Procedure of the Russian Federation (Art. 42). However, the current procedural legislation of Russia does not contain any special legal regulation providing for a procedure for considering cross-border class actions. The Russian legislator does not distinguish and does not regulate cross-border class actions, suggesting that the lawenforcer in class actions involving foreign persons should be guided by the general rules on protecting the rights and interests of a group of persons.

It is also important to touch upon the aspects of the theoretical elaboration of the problems of class action and group proceedings in domestic legal science. Despite the fact that the Russian institution of class action and group proceedings were developed on the basis of advances in this area of science, legislation and judicial law enforcement practice of foreign jurisdictions (mainly the United States), the Russian legal doctrine has adapted the models already tested by them to the unique Russian non-precedent legal system.

The difficulty lay in the fact that simple duplication and reception of normative prescriptions of foreign legal orders by embedding them in the regulatory fabric of Russian legislation without taking into account the national specifics of building a legal regulation system would not ensure the use of the full potential of the class action institution. Despite the fact that in Russian procedural law at the time of the introduction of the institution of a class action, similar constructions already existed, united, like a class action, by a plurality of persons in a legal relationship (the institution of procedural complicity), almost all aspects of a class action and group proceedings required scientific development.

It was a deep theoretical understanding of the entire toolkit of group proceedings in relation to the legal and economic realities of Russia that at the time made possible the development of means of protecting collective rights and interests in domestic procedural legislation (V.V. Yarkov [7], G.O. Abolonin [8]). And today, in Russian law, we can observe the further development of such means of protecting collective rights and interests, which, in addition to the classical institution of complicity, have been supplemented with relatively new constructions of an indirect (derivative) claim, insolvency (bankruptcy) and the class action directly related to the subject of this study.

Let us define the concept of a cross-border class action. Based on the Russian doctrine, cross-border class actions are class actions filed on behalf of a large number of foreign citizens or against foreign defendants [9]. There are variations when only part of the group includes foreign plaintiffs [10].

In the American procedural doctrine, where the concept of a class action has received its unique content and development, as well as isolation from the institution of procedural complicity, a number of law enforcement problems for US courts are identified in the context of this trend. These include difficulties in determining proper jurisdiction in class actions in accordance with Art. 23 of the US Federal Civil Procedure Rules in the need for international notification of group members, the desire of foreign group members to be included in or excluded from the group, the resolution of international disputes and the enforcement of legal decisions in class actions abroad. In addition, it states that cross-border class actions may lead to problems of determining personal and federal subject matter jurisdiction [11].

In our opinion, there is a number of legal risks and problematic issues for both the courts and the parties of the process of cross-border class actions:

- issues of determining amenability and jurisdiction in cross-border class actions;

- issues of proper and effective notification of foreign group members;

issues of joining foreign persons the submitted claim for protection of the rights and interests of a group of persons;

- issues of validity of court decisions in cross-border class actions;

- issues of recognition and enforcement of court decisions in cross-border class actions in a foreign country;

- issues of exclusion of consideration of individual actions in a foreign country after rendering the court decision in the cross-border class action. Let us consider some of them.

\section{Discussion}

The accompanying elements of cross-border class actions are likely to be recognition and enforcement of 
court decisions on the territory of foreign countries. It is important to exclude parallel and repeated cross-border class actions in different jurisdictions. In addition, guarantees are needed to ensure the rights of the defendant in a cross-border class action that foreign plaintiffs-members of the group will not bring individual actions to a foreign court after the court decision is rendered in favor of the defendant. All this must be ensured by the validity of the court decision, which is final for the parties and suggests the inadmissibility of identical actions by persons on the court decision.

Foreign experience shows that defendants of crossborder class actions experience fear of repeated trials of a similar action in foreign courts, even in case the decision is rendered in favor of a defendant. For example, in the United States, class-action defendants traditionally object to group certification and argue that European courts do not recognize a class-action court decisions in favor of the defendant or do not give it a preclusive effect [12]. In this regard, US courts act selectively and consistently, and try to analyze whether the national courts of foreign members of the group recognize the validity of the court decision in a class action before qualifying the action as a class one. The more likely it is that a foreign court will be required to recognize the cross-border class action decision, the more likely it is that the US court will include such foreign members in the group.

However, this ideal model does not always work. The court decisions in cross-border class actions can be affected by national models of class actions in accordance with the rules for involving group members in group proceedings consolidated in legislation (opt-in and opt-out models). Opt-in class actions are known as requiring active actions of a person to acquire the status of a group member and direct expression of his will to join. In contrast to the previous model, the opt-out model requires active actions of a person to leave the group, that is, the person whose rights have been violated is assumed to be a member of the group until he directly expresses his desire to be excluded from it.

Based on the comparative legal approach, it should be noted that the opt-in model is implemented in the Russian procedural law. Despite some contradictions, this conclusion is based on a number of regulations. These are the rules on the need to join the group members before the transition to judicial debate (p. 6, Art. 225.10 of the Code of Arbitration Procedure), on the need to specify the composition of the group by the plaintiff-representative (p. 2-6, Art. 225.14 of the Code of Arbitration Procedure), and on the obligation of the court to indicate the conclusions in relation to each member of the group in the operative part of the class action decision. The opt-in model best meets the challenges in organizing the execution of decisions in cross-border class actions in comparison with the opt-out model typical of the US.

However, in the Russian civil and arbitration procedural legislation, the legal force of decisions in class actions is regulated in a special way, which extends its effect on all potential plaintiffs. According to p. 2, Art. 225.17 of the Code of Arbitration Procedure of the
Russian Federation 'the circumstances established by a decision of an arbitration court that entered into legal force on a previously considered case on protection of the rights and interests of a group of persons are not proven again when the arbitration court considers another case at the request of a member of this group who has not previously joined or refused to join the claim for protection of the rights and interests of a group of persons against the same defendant and on the same subject, except in cases where these circumstances are disputed by this member of the group'. This approach to regulating the validity of a class-action court decision does not seem to be fully consistent with the opt-in model. In fact, a cross-border nature of the court decision in a class action taken by a Russian court will be revealed through the validity of this judicial act in relation to all potential group members, including foreign members.

The American opt-out model in the cross-border aspect, however, raises a larger number of problems, as noted by researchers in the legal doctrine. According to T. Monestier, 'an opt-in mechanism for foreign plaintiffs would provide several advantages over the current optout mechanism: it would eliminate the res judicata problem altogether; it would allow all foreign claimants to participate in U.S. litigation if they so choose; it would provide additional due process protections for absent foreign claimants; it would respect international comity; and it would sufficiently deter defendant misconduct' [13].

Indeed, even in the aspect that a class member acts as a party to the process, and not as a represented absent participant, the opt-in model generally perceived by the Russian legislator seems to be more effective for crossborder class actions than the opt-out model. This model will be more responsible for the organization of execution for foreign group members and correspond to the goals of the class action institution to protect the rights and interests of large groups of people, including foreigners. However, in the current Russian procedural law, a class-action court decision is not able to secure the defendant from the appearance of future individual plaintiffs from another country.

The issue that requires doctrinal and regulatory elaboration in the cross-border aspect of class actions, even with the opt-in model in Russia, is proper notification of foreign group members about the class action filed and the possibility of joining the claim. The person concerned may not learn or learn too late about a class action case, which results in a violation of the procedural rights of individuals who want to join the group and 'get the effect' of a class action judgment. Let us consider this on the example of the regulation of the arbitration procedural legislation of the Russian Federation. Thus, preparing a case on protection of the rights and legitimate interests of a group of persons for trial implies resolution of issues about the composition of a group of persons, and the possibility of identifying other participants of disputable legal relations and joining the case. The court prescribes to the plaintiffrepresentative of the group a period for inviting other persons from this group to join the claim for protection 
of the rights and legitimate interests of a group of persons (cl. 3, p. 1-2, Art. 225.14 of the Code of Arbitration Procedure).

In terms of the procedure for notification about the possibility of joining the claim filed in the Russian court, foreign members of the group may be more vulnerable than members of the group who are not abroad. The law prescribes that a proposal to join the claim for protection of the rights and interests of a group of persons must be made by a plaintiff-representative in a public form through publishing a message in the media. As an optional way of notifying the members of the group about the case and the accession, the information is posted on the official website of the arbitration court on the Internet (p. 3, Art. 225.14 of the Code of Arbitration Procedure).

Obviously, the latter notification methods does not ensure effective delivery of information to foreign members of the group using the website of the Russian court, since foreigners are unlikely to visit this website. The personification of a group of persons whose rights and interests are protected will not be fully ensured by the mechanism of notification through the media, which is proposed by the legislator in the Code of Arbitration Procedure of the Russian Federation, due to the fact that it does not consider the problems of notifying foreign members of the group.

Notification of the members of the cross-border class action group requires a special order in the mechanism of its implementation, and, consequently, special legal regulation. In order to properly and effectively inform foreign members of the group, Russian procedural law should regulate the requirements for the media used for posting a proposal to join the class action filed by the plaintiff-representative of the group. The media as a mean for notifying members of a cross-border class action group must meet the requirements of 1) the international geography that implies the territory of one or more foreign countries, and 2) the language of the published notification for the foreign group members. The key goal is to ensure maximum publicity of the proposal to join a class action filed in the Russian court in a cross-border environment. The court request for information about potential foreign group members from the defendant can also be effective. However, this is not a single method of obtaining information about group members.

The requirements for the media analyzed in a practical aspect, for example, need to be taken into account in a class action court related to the violation of the rights of buyers from Russia and foreign buyers when issuing securities. The peculiarity of Russian civil procedural law is the detail of the procedural form and, only if required, judicial discretion, which is different from the legal nature of the American procedure [14]. In this regard, the transition from court discretion to detailing of the Russian legal regulation of the procedure for notifying foreign group members in cross-border class actions will contribute to the development of the institution of class action in the cross-border aspect.

\section{Conclusion}

In the context of globalization, cross-border class actions are the reality and future of procedural law of various jurisdictions and the global economy. The analysis revealed a number of difficulties in law enforcement of class actions in the cross-border aspect, which arise when protecting the rights and interests of persons in the same legal-factual situation. All this should form the basis for further research into the institution of class action.

Current procedural legislation of the Russian Federation provides ample opportunities for protection of collective rights and legitimate interests through the construction of a class action. This became possible due to the consideration of foreign experience in legal regulation and the advantages of certain models of class actions. However, the legislator does not create special legal regulation for the consideration of cross-border class actions that involve both Russian and foreign persons, which cannot be assessed positively. A promising direction in the development of the procedural law is the use of the comparative method to study the problems of cross-border class actions, which, in terms of the methodology of legal science, will contribute to the development of the most optimal national class action model in the cross-border aspect.

\section{References}

1. A. Miller, Theoretical Inquiries in Law, 19, 42 (2018)

2. V. Yarkov, Economic Justice Bulletin, 8, 102 (2015)

3. R. Klonoff, Class Action and Other Multi-Party Litigation in a Nutshell (2017)

4. P. Zwier, V. Yarkov, Herald of Civil Procedure, 10, 145 (2020)

5. W. Aceves, University of Chicago Legal Forum, 9 (2003)

6. V. Yarkov, V. Dolganichev, Herald of the EuroAsian Law Congress, 1, 126 (2020)

7. V. Yarkov, State and law, 9, 32-40 (1999)

8. G. Abolonin, Class actions (2001)

9. R. Wasserman, Notre Dame Law Review, 86, 313 (2010)

10. T. Monestier, Tulane Law Review, 86, 1 (2011)

11. G. Shreve, P. Raven-Hansen, Understanding Civil Procedure (2009)

12. R. Wasserman, Notre Dame Law Review, 86, 313 (2010)

13. T. Monestier, Tulane Law Review, 86, 1 (2011)

14. I. Reshetnikova, Thinking about Legal Proceedings (2019) 